Scientific Paper

Doi: http://dx.doi.org/10.1590/1809-4430-Eng.Agric.v42n1e20210127/2022

\title{
INTERFERENCE OF OPERATING SPEED AND PHYSICAL PROPERTIES OF GRANULATED FERTILIZERS WITH THEIR DEPOSITION
}

\author{
Mariane C. da Costa ${ }^{1^{*}}$, Gabriel G. Zimmermann¹, Samir P. Jasper ${ }^{1}$, \\ Daniel Savi ${ }^{1}$, Gabriel A. de Oliveira ${ }^{1}$
}

${ }^{1 *}$ Corresponding author. Universidade Federal do Paraná/ Curitiba - PR, Brasil.

E-mail: condolmariane1998@gmail.com | ORCID ID: https://orcid.org/0000-0001-8352-0375

\section{KEYWORDS}

fertilization, particle size, segregation, uniformity, flow rate.

\begin{abstract}
Uniformity in the deposition of granulated fertilizers in the seed furrow is essential for crop development and productivity. Quantitative (dose and flow) and qualitative factors (segregation and formulation) influence granulated fertilizer distribution throughout its application. This experiment aimed to compare the deposition of two granulated fertilizers with different chemical formulations (04-14-08 and 04-30-10), using the helical overflow metering mechanism at three different operating speeds $(4.0,7.0$, and $10.0 \mathrm{~km}$ $\mathrm{h}^{-1}$ ), simulated on an electronic bench. The granulated fertilizers were analyzed for particle size, density, angle of repose, and water content. On the other hand, the deposition data were subjected to descriptive statistics and frequency histograms. The angle of repose and water content did not differ between fertilizers, while the density difference was not significant. The granulated fertilizer 04-30-10 presented the most uniform particle size compared to the granulated fertilizer 04-14-08. The higher particle size uniformity was responsible for a more homogeneous deposition in the seed furrow for the granulated fertilizer 04-30-10 at a speed of $4.0 \mathrm{~km} \mathrm{~h}^{-1}$, followed by $7.0 \mathrm{~km} \mathrm{~h}^{-1}$.
\end{abstract}

\section{INTRODUCTION}

Fertilizers are the most relevant agricultural inputs in the Brazilian economy. According to FAO (2019), Brazil ranked fourth in the use of mineral nutrients in 2016, representing $7.63 \%$ of the total consumption in the world. Fertilizer quality, related to particle size and uniformity, is of fundamental importance in crop productivity, considering the search for profitability (Reynaldo et al., 2016a).

Granulated fertilizer quality is related to the occurrence of segregation, which can also change the amounts of nutrients deposited along the seed furrow (Feltran et al., 2006). Segregation is the rearrangement of particles present in the mixture in order of size, shape, density, or surface texture (Farnish \& Bradley, 2007), which leads to nutrient separation and causes irregularity in the fertilizer deposition in the furrow, making it difficult to regulate seed-cum-fertilizer drills.
The correct distribution of granulated fertilizers in quantity and uniformity is important, as the rational use of this resource in agriculture contributes to the optimization of the profitability of producers, in addition to minimizing the impacts on the environment due to reduced contamination of soil and water resources (Sousa et al., 2011).

In this context, Dalacort \& Stevan (2018) stated that metering mechanisms are responsible for the regular deposition of granulated fertilizers. However, the proper functioning of these mechanisms is subject to disturbances from external factors, such as slope, operating speed, and granulated fertilizer conditions. Reynaldo et al. (2016b) also pointed out that the consistency, moisture, and fluidity of granular fertilizers are important physical properties in the variation of deposition uniformity.

\footnotetext{
${ }^{1}$ Universidade Federal do Paraná/ Curitiba - PR, Brasil.
} 
In precision agriculture, fertilizers are applied at a variable rate, according to the requirements of each area, and the metering mechanisms play a fundamental role in this process (Verardi et al., 2019). Reynaldo et al. (2016b) used a gravimetric metering mechanism at a speed of 8.0 $\mathrm{km} \mathrm{h}^{-1}$ and observed that fertilizer quality influences the efficiency of application machines and has a direct effect on the longitudinal distribution uniformity of this input. However, few studies have evaluated the influence of physical properties on the granulated fertilizer distribution at different speeds, using a single helical metering mechanism.

Thus, this study aimed to compare the performance of two granulated fertilizers with different chemical formulations at three operating speeds, simulated on an electronic bench.

\section{MATERIAL AND METHODS}

\section{Experimental bench}

The experiment was carried out on an electronic and automated bench. This technique was used in the simulation to evaluate the deposition of granulated fertilizers equipped with different metering mechanisms, under different operating conditions, without the interference of external factors (Zimmermann et al., 2020).

The experimental bench (Figure 1) has an electrical drive box (A), transmission (B) and articulation set (C), reservoirs $(\mathrm{D})$, metering mechanism $(\mathrm{E})$, and a real-time data collection system $(\mathrm{F})$. The electrical drive occurs through a frequency inverter, allowing the adjustment of the gear motor rotation, which activates the fertilizer metering mechanism through the transmission.
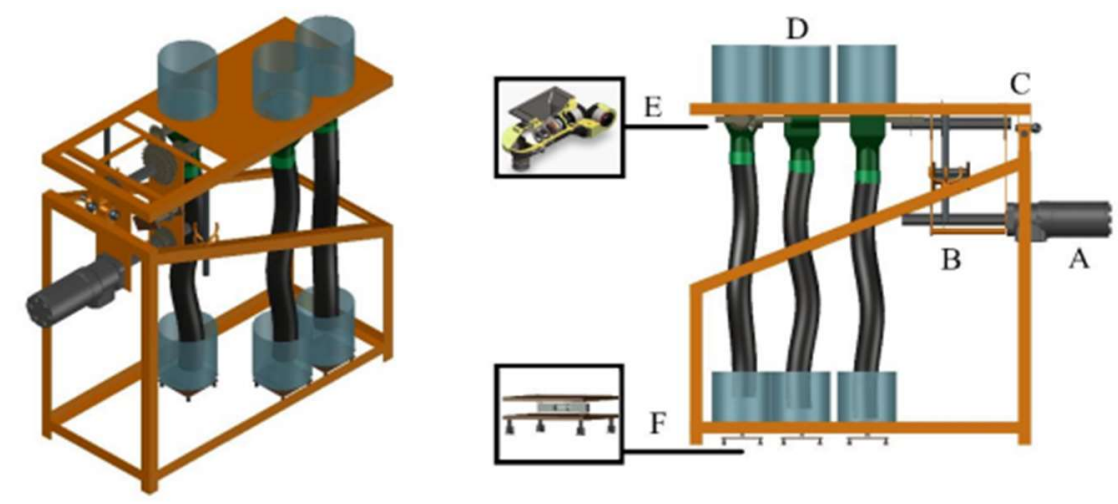

FIGURE 1. Diagonal superior and lateral projection of the electronic and automated bench.

The simulation of angular velocities was adopted based on the conversion of actual values to $\operatorname{Hertz}(\mathrm{Hz})$ in the frequency inverter, being $1.11 \mathrm{~m} \mathrm{~s}^{-1}\left(4.0 \mathrm{~km} \mathrm{~h}^{-1}\right)$ to 20.35 $\mathrm{Hz}, 1.94 \mathrm{~m} \mathrm{~s}^{-1}\left(7.0 \mathrm{~km} \mathrm{~h}^{-1}\right)$ to $35.61 \mathrm{~Hz}$, and $2.77 \mathrm{~m} \mathrm{~s}^{-1}(10.0$ $\mathrm{km} \mathrm{h}^{-1}$ ) to $50.88 \mathrm{~Hz}$. The set was parameterized to operate at a frequency from 1 to $60 \mathrm{~Hz}$, activated by a linear potentiometer of $5 \mathrm{~K} \Omega$, which allowed varying the angular velocity of the metering mechanism.

The granulated fertilizer reservoir, located at the upper end of the bench, was coupled to the single helical metering mechanism by an overflow model FertiSystem $\left(\operatorname{Agromac}^{\circledR}\right.$ ) with a one-inch step. This mechanism is the most used in most seed-cum-fertilizer drills sold in Brazil, according to previous research. The single helical metering mechanism is formed by a helicoid fixed to a rotating shaft. The shaft rotation speed controls the amount of fertilizer deposited on the soil.

\section{Data acquisition system}

The deposition of granulated fertilizers on the experimental bench was measured by a data acquisition system (DAS) with a printed circuit board at the acquisition frequency of one Hertz, connected to a hard disk for subsequent tabulation in analysis sheets. The set collected the flow rate of the granulated fertilizers 04-14-08 and 04$30-10$ in a period of 500 seconds, with the initial and final 40 seconds being discarded to stabilize the deposition. A sampling of 420 depositions was carried out for each granulated fertilizer and simulated operating speed, totaling 2,520 pieces of information.
The DAS was connected to a scale composed of a load cell (single point) with an accuracy of 0.0011 grams per pulse to quantify the mass of the deposited granulated fertilizer. Calibration was performed with 12 increasing masses (on a semi-analytical scale), transferred to the container placed on the scale, and then pulses were read in the data acquisition system for each mass. The information was correlated, generating a linear equation with a coefficient of determination of 1.00 .

\section{Characterization of granulated fertilizers}

Granulated fertilizers (GF) $\quad \mathrm{N}-\mathrm{P}_{2} \mathrm{O}_{5}-\mathrm{K}_{2} \mathrm{O}$ were selected according to the products marketed in the region and based on the phosphorus (P) concentration they had in their formulation. Two tons of GF were purchased, being divided into two formulations: 04-14-08 (GF1) and 04-3010 (GF2). According to Silva (1997), a mineral source with a high density, such as phosphorus, tends to directly influence fluidity, considering that it is one of the main types of particle movement resulting from segregation.

The formulation particle sizes (Table 1) were determined according to the Manual of Official Analytical Methods for Fertilizers and Correctives by MAPA (2017). Particle size analysis consists of measuring the passing volume of fertilizer through meshes with decreasing opening size. The used set of sieves and meshes were $4 \mathrm{~mm}$ (ABNT No. 5), 2 mm (ABNT No. 10), $1 \mathrm{~mm}$ (ABNT No. 18 ), and $0.5 \mathrm{~mm}$ (ABNT No. 35). Table 1 shows the particle size analysis with data on interaction and retention of particles on the different sieve meshes and the total passing volume of fertilizers. 
TABLE 1. Summary of the particle size analysis with data on interaction and retention of particles on different sieve meshes and total passing volume of fertilizers.

\begin{tabular}{cccc}
\hline \multirow{2}{*}{ Sieve } & \multicolumn{3}{c}{ Granulated fertilizer (GF - \%) } \\
\cline { 2 - 4 } & $04-14-08(\mathrm{GF} 1)$ & $04-30-10(\mathrm{GF} 2)$ & Mean retention \\
\hline $0.0 \mathrm{~mm}$ & 0 & 0 & 0 \\
$0.5 \mathrm{~mm}$ & 0.50 & 0 & 0.25 \\
$1.0 \mathrm{~mm}$ & 24.25 & 5.50 & 14.87 \\
$2.0 \mathrm{~mm}$ & 72.75 & 90 & 81.38 \\
$4.0 \mathrm{~mm}$ & 2.5 & 4.50 & 3.5 \\
\hline Passing $(\%)$ & 19.93 & 20.0 & \\
\hline
\end{tabular}

In addition to the deposition and particle size, the density, estimated in Dalle Molle equipment, fluidity, and water content of the fertilizers were determined according to the methodology proposed by MAPA (2017), and the results are shown in Table 2.

TABLE 2. Summary of the density analysis, angle of repose, and water content of the fertilizers.

\begin{tabular}{cccc}
\hline Granulated fertilizer $(\mathrm{GF})$ & Density $\left(\mathrm{g} \mathrm{cm}^{-3}\right)$ & Angle of repose $\left(^{\circ}\right)$ & Water content $\left(\mathrm{g} \mathrm{g}^{-1}\right)$ \\
\hline $04-14-08$ (GF1) & 0.97 & 32.55 & 0.03 \\
$04-30-10$ (GF2) & 0.95 & 33.69 & 0.03 \\
\hline
\end{tabular}

\section{Statistical analysis}

The deposition data were subjected to the JarqueBera normality test (Wijekularathna et al., 2019) and descriptive statistics, with measures of central tendency (arithmetic mean, median, and mode), dispersion (range, coefficient of variation, and standard deviation), skewness, and kurtosis. Subsequently, histograms were constructed considering the frequencies distributed in class intervals (Samohyl, 2009).

The reference values adopted for the coefficient of skewness were $\mathrm{Cs}>0$, right-skewed distribution; $\mathrm{Cs}<0$, leftskewed distribution; and $\mathrm{Cs}=0$, symmetric distribution (Correa, 2003). The reference values for the coefficient of kurtosis were $\mathrm{Ck}>0$, leptokurtic distribution; $\mathrm{Ck}<0$, platykurtic distribution; and $\mathrm{Ck}=0$ normal or mesokurtic distribution (Samohyl, 2009).

\section{RESULTS AND DISCUSSION}

The particle size analysis of the fertilizers (Table 1) presents the results referring to the sieve factor and the formulation factor of the granulated fertilizers. Regarding the sieve factor, the 2-mm mesh retained the highest amount of granulated fertilizer, followed by the 1-mm mesh, and, together, they retained more than $95 \%$ of the fertilizer particles. Regarding the formulation factor, the quantity of passing particles of GF1 and GF2 did not show a significant difference.

According to MAPA (2017), the quantities of particles passing through the 2-mm mesh sieve (ABNT No. 10) must be at most $40 \%$ for a solid fertilizer to be considered granulated. Both fertilizers were within the parameters established by ABNT, as the quantities of passing particles of granulated fertilizers GF1 and GF2 on the 2.0 -and $1.0-\mathrm{mm}$ meshes amounted to approximately $4 \%$ (Table 1).

According to ABNT, the smaller the quantity of particles retained in the smaller mesh sieve $(0.5 \mathrm{~mm})$, the higher the uniformity of the granulated fertilizer, as the formulation has a higher quantity of granulated particles and a lower quantity of powder in its composition. Thus, granulated fertilizers concentrated on larger meshes tend to be more uniform.

The results of the interaction and retention of fertilizers on the different sieve meshes (Table 1) showed that the formulation $04-14-08$ (GF1) presented $0.5 \%$ of the particles retained on the smaller mesh sieve $(0.5 \mathrm{~mm})$, while the formulation 04-30-10 (GF2) had no particles retained on the same sieve. The difference between both fertilizers was significant regarding the 1-and 2-mm mesh sieves. The 2$\mathrm{mm}$ mesh, which has the second-largest opening, increased the retention of GF1 and GF2 by 72.75 and $90 \%$, respectively. Importantly, GF2 has a higher particle size uniformity, with a higher quantity of granules than GF1.

The difference in density between both fertilizers was not significant (Table 2), as well as the angle of repose, which showed that the fertilizers have a free-flowing (angle of repose between 30 and $38^{\circ}$ ), according to the flowability classification of Woodcock \& Mason (1987). The water contents did not differ.

Table 3 shows the descriptive statistics data. The central tendency parameters (arithmetic mean, median, and mode) can be analyzed based on the asymmetry of the curve (Samohyl, 2009), and will be discussed along with the frequency plots. 
TABLE 3. Descriptive statistics of the deposition mass rate ${ }^{\mathrm{TM}}$ of fertilizers GF1 and GF2 at speeds $4.0,7.0$, and $10.0 \mathrm{~km} \mathrm{~h}^{-1}$ for a single helical metering mechanism.

\begin{tabular}{|c|c|c|c|c|c|c|}
\hline \multirow[b]{2}{*}{ Parameter } & \multicolumn{2}{|c|}{$4 \mathrm{~km} \mathrm{~h}^{-1}$} & \multicolumn{2}{|c|}{$7 \mathrm{~km} \mathrm{~h}^{-1}$} & \multicolumn{2}{|c|}{$10 \mathrm{~km} \mathrm{~h}^{-1}$} \\
\hline & $\begin{array}{c}04-14-08 \\
\text { (GF1) }\end{array}$ & $\begin{array}{c}04-30-10 \\
(\mathrm{GF} 2)\end{array}$ & $\begin{array}{c}04-14-08 \\
(\mathrm{GF} 1)\end{array}$ & $\begin{array}{c}04-30-10 \\
\text { (GF2) }\end{array}$ & $\begin{array}{c}04-14-08 \\
\text { (GF1) }\end{array}$ & $\begin{array}{c}04-30-10 \\
(\mathrm{GF} 2)\end{array}$ \\
\hline Mean & 16.52 & 15.70 & 29.71 & 28.08 & 43.99 & 39.16 \\
\hline Median & 16.43 & 15.60 & 49.48 & 27.56 & 43.75 & 38.58 \\
\hline Mode & 17.17 & 14.63 & 30.29 & 27.96 & 41.58 & 41.13 \\
\hline $\begin{array}{l}\text { Standard } \\
\text { deviation }\end{array}$ & 0.97 & 1.05 & 1.85 & 2.05 & 2.8 & 2.54 \\
\hline Range & 5.69 & 6.43 & 10.55 & 17.09 & 18.28 & 19.42 \\
\hline CV (\%) & 5.88 & 6.67 & 6.24 & 7.30 & 6.36 & 6.49 \\
\hline Skewness & 0.21 & 0.10 & 0.13 & 1.41 & 0.09 & 0.91 \\
\hline Kurtosis & -0.27 & 0.04 & -0.40 & 5.48 & -0.01 & 2.47 \\
\hline JB & $4.46 \mathrm{~N}$ & $664.64 \mathrm{~N}$ & $3.97 \mathrm{~N}$ & $664.64 \mathrm{~N}$ & $0.59 \mathrm{~N}$ & $164.95 \mathrm{~N}$ \\
\hline
\end{tabular}

$\mathrm{CV}$ - Coefficient of variation; JB - Jarque-Bera normality test (N: normal distribution; A: non-normal distribution (p < 0.05); AA: non-normal distribution $(\mathrm{p}<0.01))$.

All coefficients of variation were below $10 \%$, showing a low data dispersion (Ferreira, 2018) and, consequently, high precision in experimental sampling, meaning low standard deviation and range values, especially at a speed of $4.0 \mathrm{~km} \mathrm{~h}^{-1}$. The behavior of these parameters is due to the curve flattening, which is determined by kurtosis (Zerbato et al., 2013), also analyzed in the frequency plots.

Figure 2 shows the interaction of the fertilizer depositions analyzed as a function of the three simulated speeds. The increase in operating speed resulted in a linear increase $\left(\mathrm{R}^{2}\right.$ above $99 \%$ ) in the deposition of granulated fertilizers. In this case, GF1 showed higher deposition (approximately 10\%) than GF2 at all speeds.

\section{Interaction of the flow rate of two fertilizers}

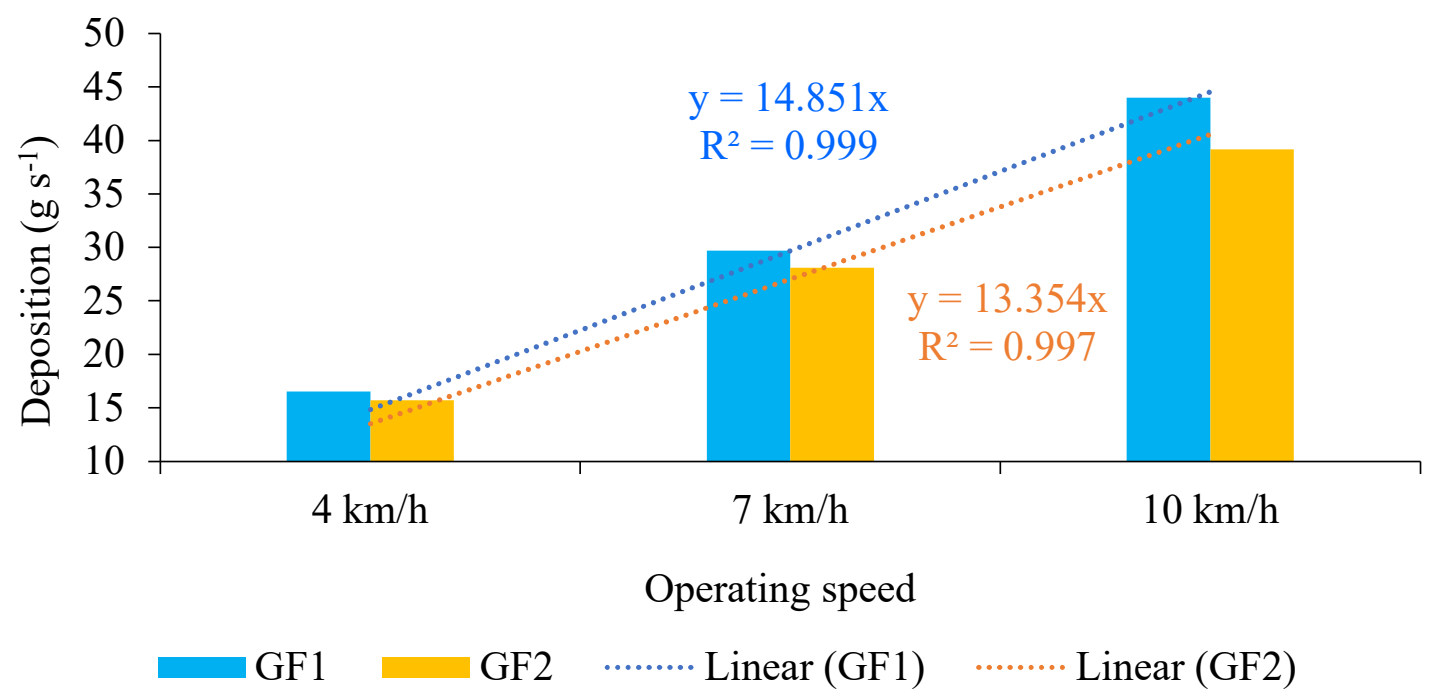

FIGURE 2. Analysis of the interaction of the flow rates of fertilizers GF1 and GF2 at three speeds $\left(4.0,7.0\right.$, and $\left.10.0 \mathrm{~km} \mathrm{~h}^{-1}\right)$.

The highest GF1 deposition is provided by its particle size composition. GF1 presents a higher quantity of powder, which are smaller and denser particles than the granules, because its formulation is more uneven. According to Feltran et al. (2006), the granulated formulation that has a higher percentage of small particles presents a high possibility of segregation during the fertilization process. According to Silveira (1989), finer and denser particles are deposited at the bottom of the reservoir and tend to be distributed first, affecting the distribution.
Therefore, the powder particles present in GF1 were deposited at the bottom of the reservoir, and these particles passed through the metering mechanism together with the granules, resulting in a higher flow rate of this fertilizer.

The performance of GF1 and GF2 was compared by analyzing their distribution behavior in five fertilizer mass deposition intervals, together with the skewness and kurtosis data shown in Table 4. The histogram is a tool to analyze the uniformity of fertilizer distribution, in which the samples are represented in class intervals and their behavior 
evaluated based on the disposition of events. In this sense, Melo et al. (2019) evaluated the quality of seed deposition using frequency histograms.

Unlike GF1, the fertilizer GF2 showed a regular distribution within the class intervals at $4.0 \mathrm{~km} \mathrm{~h}^{-1}$ (Figure 3). The skewness value for GF2 reached 0.10 , which indicates a slight right-skewed distribution, corroborated by the mean, median, and mode values (Correa, 2003), but with a reduced curve flattening, as the kurtosis value (0.04) is close to zero, which approaches a normal distribution (Silva et al., 2010). It means that the helical metering mechanism supply with GF2 at this displacement speed was carried out uniformly, that is, the fertilizer granules were released from the reservoir, by gravity, fully filling the helicoid, resulting in a homogeneous distribution and, consequently, good crop productivity. The fertilizer GF1 had a skewness of 0.21 , indicating a right-skewed distribution higher than that of GF2, while its kurtosis was -0.27 , exhibiting platykurtic distribution, with a lower concentration of deposition values around the center (Samohyl, 2009), which indicates low uniformity of distribution.

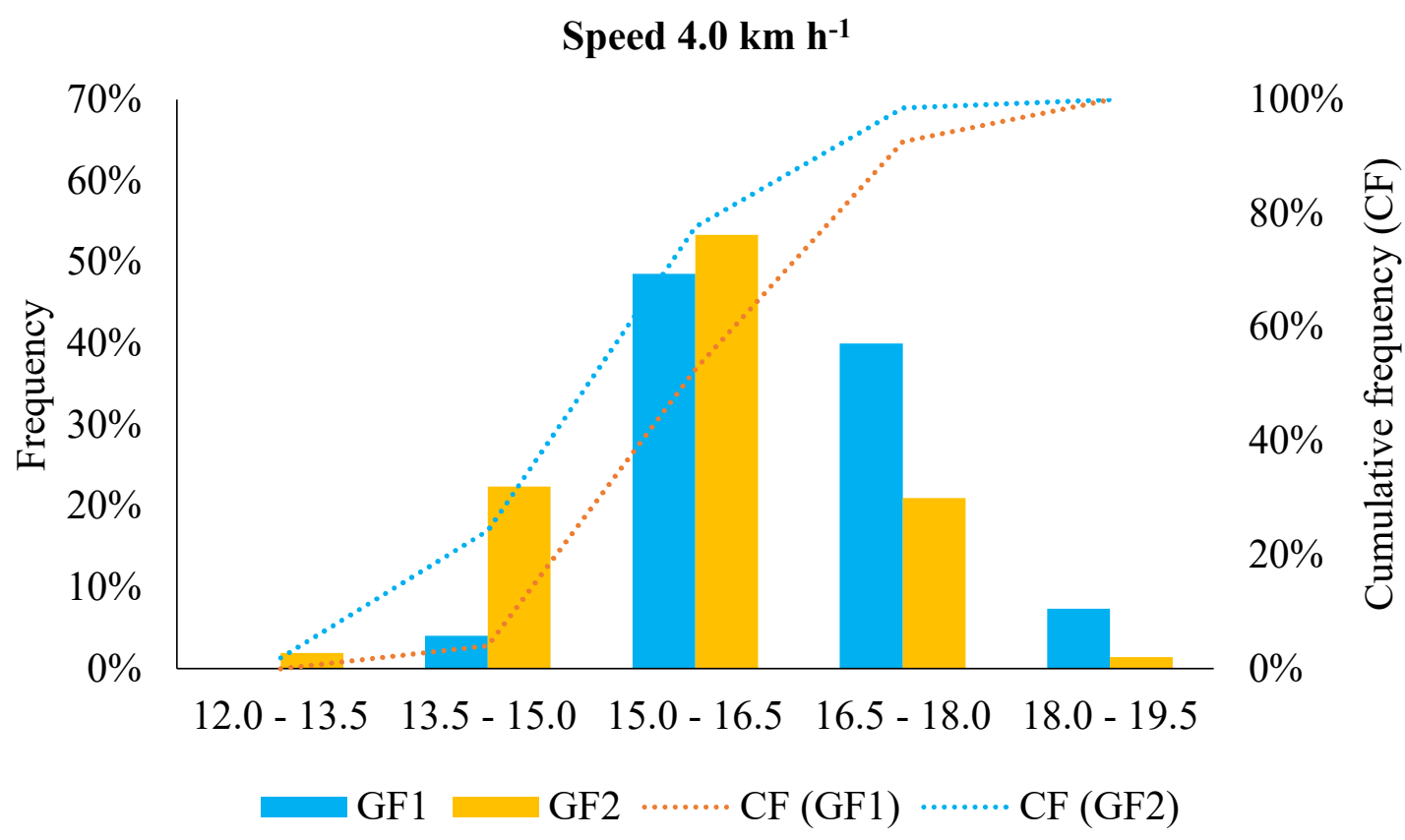

FIGURE 3. Distribution of deposition samples collected from two fertilizers at a speed of $4.0 \mathrm{~km} \mathrm{~h}^{-1}$.

Fertilizers GF1 and GF2 had a positively skewed distribution at $7.0 \mathrm{~km} \mathrm{~h}^{-1}$ (Figure 4), with skewness values of 0.13 and 1.41 , respectively, but with a lower distribution within the class intervals when compared to $4.0 \mathrm{~km} \mathrm{~h}^{-1}$. GF1 had a kurtosis value of -0.40 , indicating a platykurtic curve, with deposition values dispersed from the center, whereas GF2 presented a kurtosis value of 5.48, showing a leptokurtosis, with a higher frequency of data around the center of distribution (Samohyl, 2009). In practice, there was a failure in supplying the metering mechanism for both fertilizers due to angular velocity, that is, the helicoid was not completely filled with fertilizer granules, which caused deposition failures. According to Lange et al. (2019), fertilizer application year after year in the same seeding row changes most of soil chemical attributes, concentrating some nutrients in the row, which is a highly positive factor regarding productivity. Thus, the fertilizer distribution failure goes against this factor. 


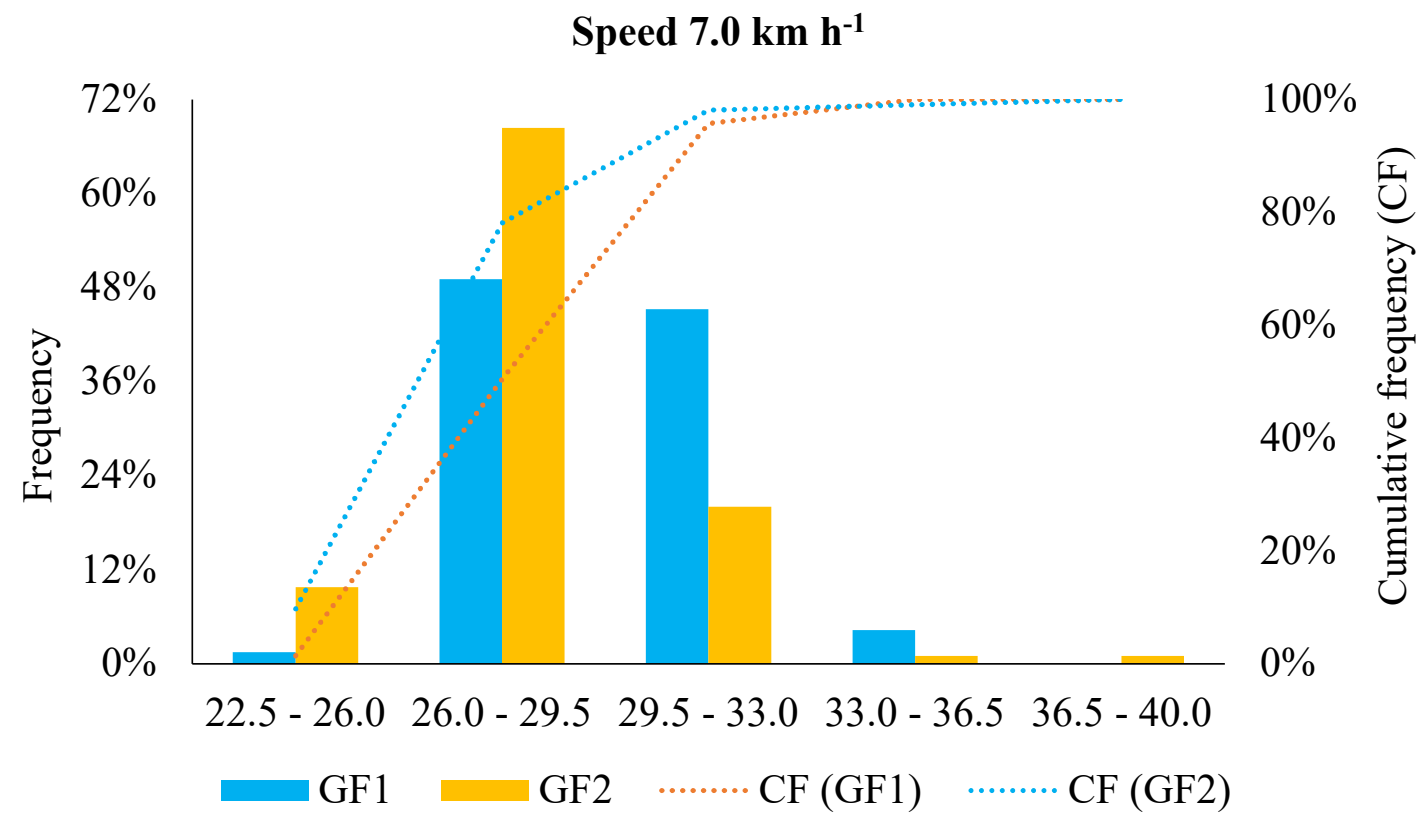

FIGURE 4. Distribution of deposition samples collected from two fertilizers at a speed of $7.0 \mathrm{~km} \mathrm{~h}^{-1}$.

Finally, the skewness values at a speed of $10.0 \mathrm{~km}$ $\mathrm{h}^{-1}$ (Figure 5) were 0.09 and 0.91 for GF1 and GF2, respectively, also occurring a right-skewed distribution. In addition, GF1 showed a kurtosis value of -0.01 , exhibiting a platykurtic distribution, while GF2 presented a kurtosis of
2.47, indicating a leptokurtic curve (Samohyl, 2009). However, both fertilizers showed the highest irregularity of distribution within the class intervals at this speed, corroborating an uneven distribution.

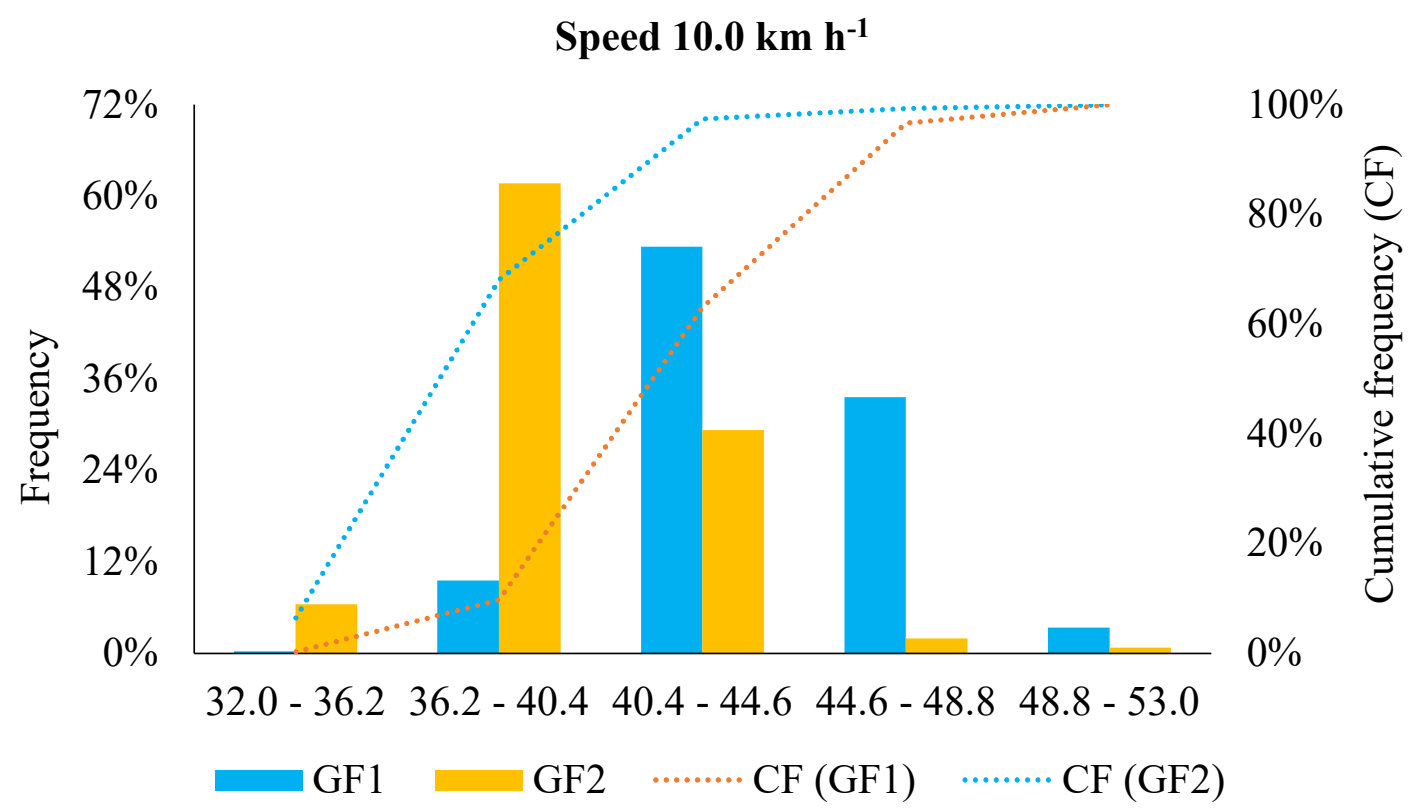

FIGURE 5. Distribution of deposition samples collected from two fertilizers at a speed of $10.0 \mathrm{~km} \mathrm{~h}^{-1}$.

The results are different from those obtained by Mantovani et al. (2015), who evaluated a corn seed-cumfertilizer drill at three different speeds $\left(5,7\right.$, and $\left.9 \mathrm{~km} \mathrm{~h}^{-1}\right)$ and concluded that the good performance in sowing was given at speed limits from 5.0 to $7.0 \mathrm{~km} \mathrm{~h}^{-1}$. Regarding fertilization, the single helical metering mechanism presented better distribution at the inter-row spacing of 0.45 $\mathrm{m}$ of the seed-cum-fertilizer drill than $0.90 \mathrm{~m}$. However, the speed variation was not significant.
According to Camacho-Tamayo et al. (2009), helical metering mechanisms are suitable for distributing granulated products at high flows rates and, consequently, higher speeds, which differs from the results found in this study. The increased speed generated an increase in the flow rate of both fertilizers, but the fertilizer GF2, which has the highest particle size uniformity, obtained the most homogeneous distribution at the lowest analyzed speed. 


\section{CONCLUSIONS}

The physical characteristic of granulated fertilizers directly influences application uniformity, that is, it is the factor responsible for the homogeneous distribution, and not just the used metering mechanism.

The fertilizer 04-30-10 (GF2) has better performance than 04-14-08 (GF1) due to its higher particle size uniformity.

The distribution efficiency of the fertilizer GF2 is higher at a speed of $4.0 \mathrm{~km} \mathrm{~h}^{-1}$, followed by $7.0 \mathrm{~km} \mathrm{~h}^{-1}$.

Particle size uniformity is crucial for choosing the operating speed.

\section{REFERENCES}

Camacho-Tamayo JH, Barbosa AM, Pérez NM, Leiva FR, Rodrigues GA (2009) Operational characteristics of four metering systems for agricultural fertilizers and amendments. Engenharia Agrícola 29 (4): 605-613.

Correa, SMBB (2003) Probabilidade e estatística. Belo Horizonte, PUC Minas Virtual.

Dalacort R, Stevan S (2018) Mobile helical capacitive sensor for the dynamic identification of obstructions in the distribution of solid mineral fertilizers. Sensors 18 (11): 3991-4010.

FAO - Food and Agriculture Organization of the United Nations (2019) FAOSTAT database. Fertilizers by nutrient. Roma, FAO, 200p.

Farnish RJ, Bradley MSA (2007) Segregation During Fertilizer Handling: Occurrence, Assessment and Control. In: The International Fertilizer Society, York, Proceedings...

Feltran JC, Corrêa JC, Brancalião SR, Villas Boas RL (2006) Segregação física e química de fertilizantes formulados. Revista Científica 34 (2): 188-196.

Ferreira PV (2018) Estatística experimental aplicada às ciências agrárias. Viçosa, UFV.

Lange A, Zandonadi RS, Gobbi FC (2019) Distribuição horizontal da fertilidade do solo em sistemas de tráfego controlado com fertilização em linha. Nativa 7 (3): 251-255.

Mantovani EC, Cruz JC, Oliveira AC (2015) Avaliação em campo de um semeadora-adubadora para semeadura de milho de alta densidade. Revista Brasileira de Milho e Sorgo 14 (1): 38-48.

MAPA - Ministério da Agricultura, Pecuária e Abastecimento (2017) Manual de métodos analíticos oficiais para fertilizantes e corretivos. Brasília, DF. 240p.

Melo RP, Albiero D, Praciano AC, Monteiro LA, Garcia AP (2019) Distribuição de sementes por punch seeder na agricultura familiar. Revista Ciência Agronômica 50 (3): 502-509.
Reynaldo ET, Machado TM, Taubinger L, Quadros D, Scwartz SR (2016a) Distribuição de fertilizantes a lanço em função da fração granulométrica. Revista Enciclopédia Biosfera 13: 487-494.

Reynaldo ET, Machado TM, Taubinger L, Quadros D (2016b) Distribuição de fertilizantes a lanço em função da qualidade do insumo. Revista Energia na Agricultura 31 (1):24-30.

Samohyl RW (2009) Controle estatístico de qualidade. Elsevier.

Silva GA (1997) The effect of the physical properties of particles of bulk-blended fertilizers on segregation by coning. Brazilian Journal of Chemical Engineering 14 (3): 100 .

Silva AS, Lima JSS, Xavier AC, Teixeira MM (2010) Variabilidade espacial de atributos químicos de um Latossolo Vermelho-amarelo húmico cultivado com café. Revista Brasileira de Ciência do Solo 34 (1):15-22.

Silveira GM (1989) As máquinas para plantar: aplicadoras, distribuidoras, semeadoras, plantadoras e cultivadoras. Rio de Janeiro, Globo.

Sousa LFRA, Silva WA, Silva RV (2011)

Desenvolvimento de um aplicativo computacional para a recomendação de adubação e calagem para a cultura do milho (Zea mays L.) no estado do Maranhão, Brasil.

Revista Agroecossistemas 3 (1): 36-40.

Verardi J, Rosa DP, Zancan A, Conte P, Longaretti M, Spagnolo RT (2019) Distribuição longitudinal de fertilizante granulado em diferentes inclinações e posição da rosca de um dosador de rosca helicoidal dupla. Revista Tecnología En Marcha 32 (1): 128-134.

Zerbato C (2013) Controle estatístico de processo aplicado à colheita mecanizada de milho. Revista Engenharia na Agricultura 21 (3).

Zimmermann GG, Jasper SP, Kmiecik LL, Strapasson Neto L, da Silva TX, Oiole YA (2020) Development of test bench to determine the distribution of granular fertilizers in planting rows using spiral roller, two spiral rollers and fluted roller. Plos one 15(12): e0243799. 383.

Wijekularathna DK., Manage ABW, Scariano SM (2019) Power analysis of several normality tests: A Monte Carlo simulation study. Communications in Statistics Simulation and Computation 1-18.

Woodcock CR, Mason JS (1987) Bulk solids handling. New York, Springer. 260p. 